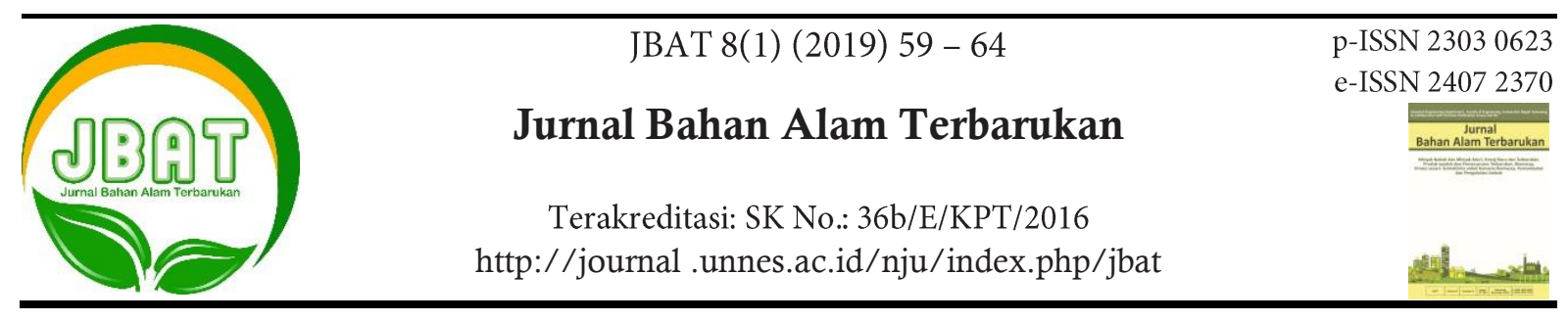

\title{
Extraction and Characterization of Coffee Oil From Instant-Coffee Waste
}

\author{
Muhammad Hanif ${ }^{凶}$, Fahmi Alif Utama Harahap, Heru, Yuli Darni, Simparmin Br. Ginting
}

DOI 10.15294/jbat.v8i1.18619

Departement of Chemical Engineering, Universitas Lampung, J1. Prof. Soemantri Brojonegoro No.1 Gedong Meneng, Bandar Lampung 35145, Indonesia

\begin{tabular}{|c|c|}
\hline Article Info & Abstract \\
\hline $\begin{array}{l}\text { Article history: } \\
\text { Received } \\
\quad \text { April } 2019 \\
\text { Accepted } \\
\quad \text { June } 2019 \\
\text { Published } \\
\quad \text { June } 2019 \\
\text { Keywords : } \\
\text { Biodiesel; } \\
\text { Coffee oil; } \\
\text { Instant-coffee waste; } \\
\text { Robusta coffee; } \\
\text { Soxhlet extraction }\end{array}$ & $\begin{array}{l}\text { The higher demands of fossil energy usage are currently imbalance to its reserves. This issue } \\
\text { will give a potency of fossil fuel scarcity that contributes on rising of its cost and disturbing } \\
\text { economic stabilization in the future. It is desirable to find another resource which is } \\
\text { sustainable and renewable to reduce the dependency on this resource. This study aimed to } \\
\text { utilize the oil from instant coffee waste as biodiesel feedstocks. The coffee oil was extracted } \\
\text { from instant-coffee waste by Soxhlet extractor and characterized its physical and chemical } \\
\text { properties. The solvent extraction through the solid bed of coffee ground performed by five } \\
\text { cycles interval using n-hexane as a solvent. Separation processing oil from its hydrocarbon } \\
\text { solvent was in a rotary vacuum evaporator and the oil extract collected for further purposes. } \\
\text { There was about } 17.6 \% \text { (on a dry weight basis) of coffee oil gained on } 20 \text { cycles of extraction. } \\
\text { Analysis regarding its physicochemical properties reported that the crude oil has } 0.89 \mathrm{~g} / \mathrm{mL} \\
\text { of density, } 43.82 \mathrm{~mm}^{2} / \mathrm{s} \text { of kinematic viscosity, } 44.47 \mathrm{mg} \mathrm{KOH} / \mathrm{g} \text { of acid value, and } 176.40 \\
\text { mg KOH/g of saponification value. The fatty acids composition of the oil provided by GC- } \\
\text { MS analyzer showed that unsaturated fatty acids contained, observed as trans-fatty acids } \\
\text { rather than cis-fatty acids. }\end{array}$ \\
\hline
\end{tabular}

\section{INTRODUCTION}

The energy issue has been one of the crucial problems due to the human population raised, environmental impacts, and its reserves. As one of the primary energy resources, petroleum still plays a role as the most significant supply energy in many parts of the world. Including in Indonesia, as it was reported statistically by Indonesia Ministry of Energy and Mineral Resource, in 2016, petroleum supplied to about $33.19 \%$ of energy needs in Indonesia (Figure 1). Since it is believed that crude oil is one of the unrenewable resources, its availability will gradually decline day by day. This argument is supported by the fact that in the last three years, the proven oil reserved in Indonesia is getting lower to about 3.17 billion barrels (2017) from 3.31 billion barrels (2016) and 3.60 billion barrels (2015) respectively (Ministry of Energy and Mineral Resources, 2017).

The highest consumption of energy in Indonesia derived from an industrial, household, and transportation sectors. Among the type of fuel oil, diesel likes automotive diesel oil (ADO), industrialized diesel oil (IDO), and biodiesel is one of the most fuel oil widely used. The utilization of petroleum diesel is still more reasonable and economical even though there is a limitation of its feedstock. However, due to energy scarcity problem in the future, efforts to reduce the use of petroleum energy sources is getting higher by increasing of biofuels application. The idea to apply biodiesel as petroleum diesel substitute has been made in the last decades by improving the research and development relates to its production.

The synthesis of biodiesel can be done through transesterification of triacylglycerol (TAG)

\footnotetext{
${ }^{\square}$ Corresponding author:

Departement of Chemical Engineering, Universitas Lampung, J1. Prof. Soemantri

Brojonegoro No.1 Gedong Meneng, Bandar Lampung 35145, Indonesia

E-mail: muhammad.hanif@eng.unila.ac.id
} 
and alcohol in the presence of an alkaline catalyst. TAG is the largest of the lipid components in a biomass source. A triglyceride molecule is formerly called "oil" if it is liquid and "fat" if it is solid at normal (ambient) condition (Gupta, 2017). Among its products, Fatty Acid Methyl Ester (FAME) is the most biodiesel produced, using methanol as the alcohol. The FAME production depends on the percentage of free fatty acid (FFA) in the oil by means, oil with FFA content $0.5-1 \%$ can be transesterified directly to form FAME (Canakci \& Van Gerpen, 2001). Also, preliminary treatment is needed to convert FFA to FAME in the presence of acid catalysts, such as sulfuric acid for more than $1 \%$ of FFA content.

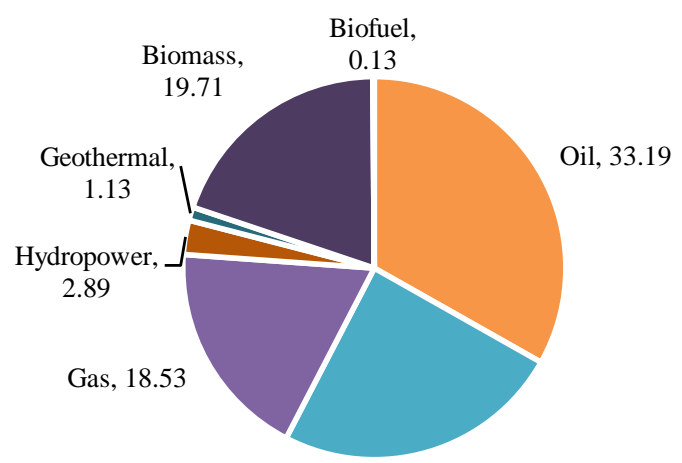

Coal, 24.43

Figure 1. Percentage of primary energy supply in Indonesia (Ministry of Energy and Mineral Resources, 2017).

About 70 to $80 \%$ of the total cost of biodiesel production comes from raw material costs (Gui et al., 2008). Reducing the cost of raw materials, the manufacturing of biodiesel becomes feasible to develop. In Indonesia, palm oil is still regarded as a primary resource for its preparation. However, palm oil is also the primary source of edible oil, besides other purposes. Therefore, this usage for biodiesel need will no longer be a good idea to develop in the future. Utilization of a waste stream as an alternative source is believed to be a promising solution to overcome environmental problems, as well as competition between food and energy supply.

Indonesia is the largest coffee producing country in the world besides Brazil, Vietnam, and Colombia. International Coffee Organization (2016) released that Indonesia could produce 691,500 tons/year of coffee. Robusta and Arabica are two main corps from Indonesia. Comparing to Arabica, the crops of Robusta coffee is too much higher, dominantly planted in some regions of Indonesia, and herewith, it is also widely used in instant-coffee manufacturing. Instant coffee waste is one of an industrial waste stream that has not been widely used yet. One instant-coffee plant could dispose of about four tons per day of spent coffee and possible to apply as a biodiesel feedstock.

A green bean of Robusta coffee contains 9.0 to $13 \%$ of fat and rise to about 11.0 to $16.0 \%$ after roasting (Wei \& Tanokura, 2015). TAG is the highest lipid component that could reach about $75 \%$ on a dry weight basis in a coffee bean (Speer \& Kölling-Speer, 2006).

Upgrading of coffee waste as a biodiesel raw material has developed since the use of defect coffee beans (Oliveira et al., 2006; Oliveira et al., 2008). Further experiments then conducted to study the potential of spent coffee ground as an alternative source (Kondamudi et al., 2008; Couto et al., 2009; Al-Hamamre et al., 2012; Abdullah \& Koc, 2013; de Melo et al., 2014; Phimsen et al., 2016). Various extraction method developed besides Soxhlet extraction to determine the extracted oil likes supercritical fluid extraction (Couto et al., 2009; de Melo et al., 2014), and two-phase solvent extraction assisted by ultrasonication (Abdullah \& Koc, 2013). Phimsen et al. (2016) have synthesized green diesel through a catalytic hydrotreating process from the spent coffee ground.

Instant-coffee waste is one of an industrial waste stream that has not been widely used yet. One instant-coffee plant could dispose of about four tons per day of spent coffee and possible to apply as a biodiesel feedstock. Instant-coffee waste is more accessible in collection term than spent coffee used in the previous studies. Nevertheless, different processing on instant-coffee production might influence the quality of oil contained. Thus, in this study, the oil was extracted from instant-coffee waste through Soxhlet extractor and determine its physical and chemical properties for a biodiesel feedstock purpose.

\section{MATERIALS AND METHODS}

\section{Instant-Coffee Waste}

The instant-coffee waste was derived from one of the industrial instant-coffee in Indonesia. The coffee beans are from Robusta species. These samples were prepared by drying wet coffee waste in the oven at $105^{\circ} \mathrm{C}$ and scaling its weight in every 15 minutes intervals until constant weight reached. 
The samples then pulverized by a conventional coffee grinder and filtered to have a size from 100 to 200 mesh. The filtered coffee grounds have $5.41 \pm 0.04 \%$ of water content subjected to plastic containers and placed in a desiccator for further treatment.

\section{Solvent}

The n-hexane technical grade was a solvent chosen to conduct leaching through Soxhlet apparatus. $\mathrm{N}$-hexane is a non-polar organic solvent and capable of extracting higher oils (Al-Hamamre et al., 2012). This hydrocarbon also has a relatively lower boiling point than other chemicals and more efficient in heat utilization. The solvent supplied from one of a laboratory and chemicals store in Bandar Lampung.

\section{Soxhlet Extraction and Oil Recovery}

Amount of $20 \mathrm{~g}$ sample of coffee grounds loaded into Soxhlet extractor. N-hexane was prepared about $500 \mathrm{~mL}$ and put into two necks round boiling flask. The extractor apparatus constructed and cooling water recirculated in a condenser by a pneumatic pump. Solvent extraction started by switching on the heating mantle, beginning from five cycles, and repeated by five cycles interval. The leaching held around the boiling point of $\mathrm{n}$-hexane and terminated until there was no significant difference in the extracted oil result. The solvent removed from the mixture by a rotary vacuum evaporator and ended about 5 to 10 minutes until there was no droplet of $n$-hexane observed. The percentage of extracted coffee oil on a dry weight basis defined as the ratio of coffee oil, $\mathrm{w}_{\mathrm{o}}$ to the coffee ground, $\mathrm{w}_{\mathrm{s}}$ :

$$
\text { extracted oil }=\frac{\mathrm{w}_{\text {oil }}}{\mathrm{w}_{\text {sample }}} \times 100 \%
$$

\section{Physicochemical Characterization}

The density, viscosity, acid value, and saponification value of coffee oil result was determined to characterize its physicochemical properties. The pycnometer method was used to measure the coffee oil density correspond to ambient temperature. The Ostwald viscometer is used to determine its viscosity. Both acid value (AV) and saponification value (SV) were obtained by titration according to standard procedures. AV of the oil was determined according to AOCS Ca $5 \mathrm{a}-40$, resulted by multiplication of FFA to 1.99
(Wrolstad, et al., 2005). The FFA content calculated according to Eq. (2).

$\% \mathrm{FFA}=\frac{\text { volume }_{\mathrm{NaOH}}(\mathrm{mL}) \times \mathrm{N}_{\mathrm{NaOH}} \times 28.2}{\mathrm{w}_{\text {oil }}}$

The saponification value (SV) was determined according to the AOCS Cd 3-25 method. The amount of $0.5 \mathrm{~N}$ of $\mathrm{HCl}(\mathrm{mL})$ needed to titrate the blank (B) and sample (S), and about 2 $\mathrm{g}$ of the coffee oil sample is used to calculate SV relating to Eq. (3) (Wrolstad et al., 2005).

$$
\mathrm{SV}=\frac{(\mathrm{B}-\mathrm{S}) \times 0.5}{\mathrm{~W}_{\mathrm{oil}}} \times 56.1
$$

\section{Analysis of Fatty Acid Composition}

The GC-MS QP-2010S Shimadzu analyzed the fatty acid compounds and its composition in the oil. The gas chromatography has specifications: Agilent HP 1MS type of column, 30 $\mathrm{m}$ long, $0.25 \mathrm{~mm}$ ID, $0.25 \mathrm{um}$ film. The carrier gas was Helium with ionizing EI 70 Ev. Oven column temperature was $50^{\circ} \mathrm{C}$, injection temperature $300^{\circ} \mathrm{C}$, pressure $12 \mathrm{kPa}$, total flow $40 \mathrm{~mL} / \mathrm{min}$, column flow $0.54 \mathrm{~mL} / \mathrm{min}$. The MS reading started at 1.8 minutes was performed up to 60 minutes. The oil was firstly transesterified to obtain FAME. FAME was produced by reacting the oil sample with $1: 3(\mathrm{v} / \mathrm{v})$ methanol in the presence of the $\mathrm{BF}_{3}$ catalyst. The reaction was carried out at $60^{\circ} \mathrm{C}$ for 1 hour then cooled and extracted with n-hexane. The upper layer was taken and injected into the GCMS for analysis. The mass spectrum adjusted referred to the GC-MS library (Wiley 229). The composition of fatty acids was determined by the percentage of peak areas from the chromatogram.

\section{RESULTS AND DISCUSSION}

\section{Percentage of The Extracted Coffee Oil}

The extracted oil obtained on 20 cycles of Soxhlet extraction (equal to 145 minutes) was $17.6 \%$ on a dry weight basis. This result did not differ significantly from 25 cycles of leaching. Couto et al. (2009) gained slightly higher (18.3\%). Meanwhile, other studies lower to this result, i.e., Al-Hamamre, et al. (2012) (15.28\%), de Melo et al. (2014) (15\%), and Phimsen et al. (2016) (10 to 13\%). The distinction in moisture content, particle size, and the species of coffee bean used might influence the yield of extraction. Besides, the 
Table 1. The Physical and Chemical Properties of The Extracted Coffee Oil

\begin{tabular}{lccccc}
\hline Property & Unit & This work & $\begin{array}{c}\text { Al-Hamamre et al. } \\
(\mathbf{2 0 1 2 )}\end{array}$ & $\begin{array}{c}\text { Caetano et al. } \\
\mathbf{( 2 0 1 2 )}\end{array}$ & $\begin{array}{c}\text { Abdullah \& Koc } \\
(\mathbf{2 0 1 3 )}\end{array}$ \\
\hline Density & $\mathrm{g} / \mathrm{mL}$ & 0.89 & 0.929 & 0.917 & 0.89 \\
Kinematic viscosity & $\mathrm{mm}^{2} / \mathrm{s}$ & 43.82 & 55.473 & 22.23 & 62.0 \\
Acid value & $\mathrm{mg}_{\mathrm{KOH}} / \mathrm{g}$ & 44.47 & 7.3 & 118.4 & - \\
Saponification value & $\mathrm{mg}_{\mathrm{KOH}} / \mathrm{g}$ & 176.40 & - & - & - \\
\hline
\end{tabular}

difference in coffee processing might give the result varied. In instant-coffee manufacturing, the coffee bean was contacted directly to the hot water which its temperature is between 160 to $180^{\circ} \mathrm{C}$ and pressure is between 14 to 16 bar (Viani \& Petracco, 2007). This condition potential to progress hydrolysis thermally of TAG. A mixture of diacylglycerol (DAG), monoacylglycerol (MAG), FFA, and glycerol might gain as a result of dissociation of TAG (Folstar, 1985; Frankel, 2005).

\section{The Physcal and Chemical Properties of The Extracted Coffee Oil}

Table 1 illustrates the physical and chemical properties of extracted oil obtained from the physicochemical analysis. The coffee oil density obtained from this study was similar to that Abdullah \& Koc (2013) observed $(0.89 \mathrm{~g} / \mathrm{ml})$, but it was slightly lower than other results, i.e., 0.929 $\mathrm{g} / \mathrm{ml}$ (Al-Hamamre et al., 2012), $0.917 \mathrm{~g} / \mathrm{ml}$ (Caetano et al., 2012) respectively. The kinematic viscosity of the coffee oil in this study was 43.82 $\mathrm{mm}^{2} / \mathrm{s}$. This result was lower moderately compared to Al-Hamamre et al. (2012), $55.473 \mathrm{~mm}^{2} / \mathrm{s}$ and Abdullah \& Koc (2013), $62.0 \mathrm{~mm}^{2} / \mathrm{s}$, but almost twice higher compared to Caetano et al. (2012), $22.23 \mathrm{~mm}^{2} / \mathrm{s}$.

Acid value (AV) and saponification value (SV) are other properties determine the quality of oils. AV corresponds to FFA content of the oil and defines as the amount of $\mathrm{KOH}$ needed to neutralize the free acid contained in the oil. The presence of FFA in the oil was $22.35 \%$ (equals to 44.47 of AV). This result is too much higher than Al-Hamamre et al analyzed, namely 7.3. In contrast, this acid value is still sharply lower than study conducted by Caetano et a (118.4 of AV). The high of AV in this study presumably as results of direct contact between the coffee bean and hot water during the brewing process in instant-coffee manufacturing. The moisture in oil responsible for increasing the FFA level through hydrolyzing of TAG and could be accelerated by heat and pressure (Wan, 2000). One-step esterification could produce unwanted soap due to a basic catalyst involved reacting with the FFA. Therefore, for this result, it is more convenient to proceed the crude oil in two-step esterification process by reducing its FFA content first with an acid catalyst and then continuing with a basic catalyst in biodiesel preparation.

Another chemical properties, SV of the oil was also measured and the value of SV to 176.40 $\mathrm{mgKOH} / \mathrm{g}$ reported. This result is close to the previous result, that is $173.9 \mathrm{mgKOH} / \mathrm{g}$ using spent coffee ground as a subject (Al-Hamamre, et al., 2012). The saponification value is defined as the amount of alkali required to saponify a certain amount of oil. The SV is inversely proportional to the average molecular weight of an oil (Wan, 2000) therefore, a low value of SV indicates longer fatty acids (Wrolstad, et al., 2005).

\section{The Fatty Acid Composition of The Extracted Coffee Oil}

The fatty acid composition from extracted oil is represented by fatty acid methyl ester profiles through TGA transenstericiation and shown by Figure 2 and Table 2 respectively. The mass spectrometer reading based on the GCMS library (Wiley 229) observed on Table 3 including previous result as its comparison. The main fatty acid components observed via GCMS scanning but most of them particularly have transformed from cisfatty acids to trans- fatty acids. This results are different from prior study, reported that the fatty acid profiles were independent of the processing of raw materials (green versus roasted), the preparation method (coffee brew versus filtration), and also the extraction method (Soxhlet vs. supercritical $\mathrm{CO}_{2}$ ) (de Melo et al., 2014). The highest fatty acid component in coffee oil is elaidic (43.94\%), followed by linoleaidic (30.05\%), stearic $(12.99 \%)$, palmitic (11.03\%) and arachidic $(1.99 \%)$ respectively.

Unsaturated fatty acids are unstable and are very susceptible to conduct oxidation even at ambient temperatures (Gupta, 2017). However, hydrogen atoms on opposite sides of the double bond (trans-form) are thermodynamically more stable. When there is enough chemical energy, such 


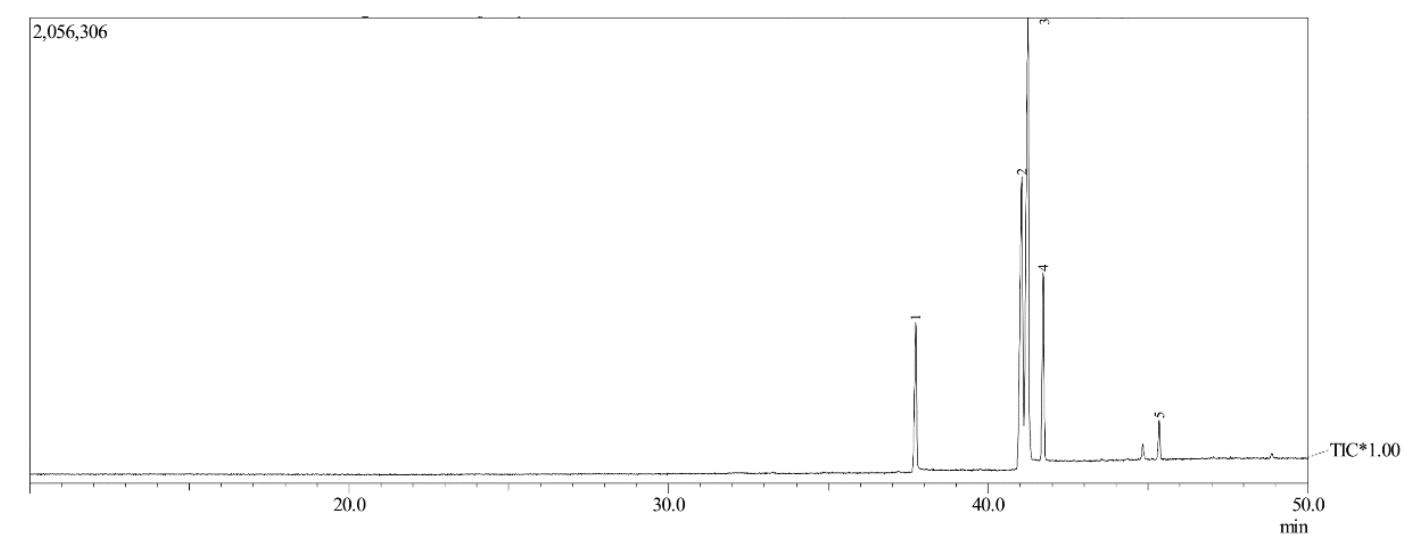

Figure 2. The chromatogram of fatty acids profile from coffee oil

Table 2. The Identity of Components of The Coffee Oil from Chromatorgam

\begin{tabular}{llllll}
\hline Peak & R.Time & I.Time & F.Time & Area & Area\% \\
\hline 1 & 37.734 & 37.633 & 37.817 & 2859012 & 11.03 \\
2 & 41.052 & 40.900 & 41.117 & 7791050 & 30.05 \\
3 & 41.249 & 41.117 & 41.367 & 11391808 & 43.94 \\
4 & 41.725 & 41.642 & 41.808 & 3369008 & 12.99 \\
5 & 45.350 & 45.300 & 45.425 & 516115 & 1.99 \\
\hline
\end{tabular}

Table 3. Fatty acids profile of the extracted coffee oil obtained by Soxhlet extraction

\begin{tabular}{lccccc}
\hline Fatty acid & & This work & $\begin{array}{c}\text { Couto et al. } \\
(\mathbf{2 0 0 9 )}\end{array}$ & $\begin{array}{c}\text { Abdullah \& Koc } \\
\mathbf{( 2 0 1 3 )}\end{array}$ & $\begin{array}{c}\text { de Melo et al. } \\
\text { (2014) }\end{array}$ \\
\hline Lauric & $\mathrm{C} 12: 0(\mathrm{wt} \%)$ & - & 3.57 & - & - \\
Myristic & $\mathrm{C} 14: 0(\mathrm{wt} \%)$ & - & 1.99 & - & - \\
Palmitic & $\mathrm{C} 16: 0(\mathrm{wt} \%)$ & 11.03 & 43.65 & 35.16 & 37.37 \\
Stearic & $\mathrm{C} 18: 0(\mathrm{wt} \%)$ & 12.99 & 6.49 & 7.89 & 7.07 \\
Oleic & $\mathrm{C} 18: 1(\mathrm{wt} \%)$ & - & 8.15 & 8.73 & 8.31 \\
Elaidic & $\mathrm{C} 18: 1(\mathrm{wt} \%)$ & 43.94 & - & - & - \\
Linoleic & $\mathrm{C} 18: 2(\mathrm{wt} \%)$ & - & 32.45 & 44.52 & 44.67 \\
Linoleaidic & $\mathrm{C} 18: 2(\mathrm{wt} \%)$ & 30.05 & - & - & - \\
$\alpha$-linoleic & $\mathrm{C} 18: 3(\mathrm{wt} \%)$ & - & 1.31 & 1.09 & 1.42 \\
Arachidic & $\mathrm{C} 20: 0(\mathrm{wt} \%)$ & 1.99 & 2.39 & 2.62 & 1.16 \\
\hline
\end{tabular}

as through oxidation or hydrogenation, the cisdouble bonds may be isomerized to form transdouble bonds, which are often accompanied by positional shifts of the double bond on the aliphatic carbon chain (Wan, 2000; Gupta, 2017).

\section{CONCLUSION}

This study reveals physical and chemical properties distinct between oil from instant-coffee waste and oil from green coffee beans and others from the spent coffee ground. Further investigation is needed to synthesize biodiesel from the coffee oil to measure its quality and to know whether it will have future prospects as another alternative resource of biodiesel feedstocks. Regarding its sufficient volume available and amount of oil content within, and also easy to handle, instantcoffee waste will be promising as a sustainable reserve.

\section{ACKNOWLEDGEMENTS}

The authors appreciate the research support provided by Central Biomass Laboratory Universitas Lampung and PT Sucofindo (Persero) Bandar Lampung.

\section{REFERENCES}

Abdullah, M., Koc, A. B.. 2013. Oil removal from waste coffee grounds using two-phase 
solvent extraction enhanced with ultrasonication. Renewable Energy. 50: 965-970.

Al-Hamamre, Z., Foerster, S., Hartmann, F., Kröger, M., Kaltschmitt, M. 2012. Oil extracted from spent coffee grounds as a renewable source for fatty acid methyl ester manufacturing. Fuel. 96: 70-76.

Canakci, M., Van Gerpen, J. 2001. Biodiesel Production from Oils and Fats with High Free Fatty Acids. Transactions of the ASAE. 44(6): 1429-1436.

Couto, R. M., Fernandes, J., da Silva, M. G., Simões, P. C. 2009. Supercritical fluid extraction of lipids from spent coffee grounds. The Journal of Supercritical Fluids. 51(2): 159-166.

De Melo, M. M. R., Barbosa, H. M. A., Passos, C. P., Silva, C. M. 2014. Supercritical Fluid Extraction of Spent Coffee Grounds: Measurement of Extraction Curves, Oil Characterization and Economic Analysis. The Journal of Supercritical Fluids. 86:150-159.

Folstar, P. 1985. Lipids. in : R. J. Clark \& R. Macrae, Ed. Coffee chemistry 1. London: Elsevier Applied Science. 203-222.

Frankel, E. N. 2005. Lipid oxidation. $2^{\text {nd }}$ Ed. Cambridge: Woodhead Publishing Limited.

Gui, M. M., Lee , K. T., Bhatia, S. 2008. Feasibility of edible oil vs. non-edible oil vs. waste edible oil as biodiesel feedstock. Energy. 33: $1646-1653$.

Gupta, M. K. 2017. Practical Guide to Vegetable Oil Processing. $2^{\text {nd }} E d$. London: Elsevier Inc.

International Coffee Organization, 2016. Trade Statistics Tables. Available at: http://www.ico.org/prices/proproduction.pdf [Online Access 20 October 2016].

Kondamudi, N., Mohapatra, S. K., Misra, M. 2008. Spent Coffee Grounds as a Versatile Source of Green Energy. Journal of
Agricultural and Food Chemistry. Volume 56: $11757-11760$.

Ministry of Energy and Mineral Resources. 2017. 2017 Handbook of Energy \& Economic Statistics of Indonesia, Jakarta: Ministry of Energy and Mineral Resources Republic of Indonesia.

Oliveira, L. S., Franca, A. S., Camargos, R. R., Ferraz, V. P. 2008. Coffee oil as a potential feedstock for biodiesel production. Bioresource Technology, 99(8): 3244-3250.

Oliveira, L. S., Franca, A. S., Mendonca, J. C., Barros-Junior, M. C. 2006. Proximate composition and fatty acid profile of green and roasted defective coffee beans. LWT Food Science and Technology. 39(3): 235239.

Phimsen, S., Kiatkittipong, W., Yamada, H., Tagawa, T., Kiatkittipong, K., Laosiripojana, N., Assabumrungrat, S. 2016. Oil extracted from spent coffee grounds for bio-hydrotreated diesel production. Energy Conversion and Management. 126: 1028-1036.

Speer, K., Kölling-Speer, I. 2006. The lipid fraction of the coffee bean. Brazilian Journal of Plant Physiology. 18(1): 201-216.

Viani, R., Petracco, M. 2007. Coffee. in: Ullmann's Encyclopedia of Industrial Chemistry. $7^{\text {th }}$ Ed. Weinheim: Wiley-VCH, pp. 467-498.

Wan, P. J. 2000. Properties of Fats and Oils. in: R. D. O'Brien, W. E. Farr \& P. J. Wan, $1^{\text {st }}$ Ed. Introduction to Fats and Oils Technology. Champaign, Illinois: AOCS Press. 20-48.

Wei, F., Tanokura, M. 2015. Chemical Changes in the Components of Coffee Beans during Roasting. in: P. R. Preedy, $1^{\text {st }}$ Ed. Coffee in Health and Desease Prevention. London: Academic Press, 83-91.

Wrolstad, R. E., Decker, E. A., Schwartz, S. J., Sporns, P. 2005. Handbook of Food Analytical Chemistry - Water, Proteins, Enzymes, Lipids, and Carbohydrates. New Jersey: John Wiley \& Sons, Inc. 